\title{
The Doklam Standoff Revisited: A Content Examination of Sino-Indian Media
}

\author{
Saloni Gupta
}

\begin{abstract}
The research aimed to find the cues that Indian and Chinese news media gave to indicate that they had an agenda on Doklam standoff. It was further augmented with evaluation of China threat notion and attempts to create illusory truth effect in the news content. By executing content analysis, it was discerned that both Indian and Chinese news media hosted all the cues confirming that they had a pre-defined agenda on the coverage of Doklam standoff and that the agenda was bestowed on the media by the government. While Xinhua had an agenda to repeatedly justify China's position on Doklam and highlight the possibilities of war by shifting the onus of the same on India, PTI had an agenda to give space to voices of all parties involved, to repeatedly restate the negative implications of standoff and all the threats it was getting from China. The findings not only suggested what was explicit in the news agenda, but also indicated the implicit or the undesirable; thus, it was found that both Indian and Chinese news media besides advancing their agenda were even contingently confirming to the notions of China threat theory and were attempting to create an illusory truth effect.

Keywords: 2017, Agenda setting, China threat, China, content analysis, Doklam Standoff, illusory truth, India, media, Sino.
\end{abstract}

\section{INTRODUCTION}

The existing studies on media coverage during wartime have suggested: "on the whole, media have "served the military rather well" during times of war" (Carruthers, 2000, pp.271-2; Taylor, 1992, cited in Murray et al.,2008, p.9). The factors that explain "media deference to government war objectives" revolve around "dependence on official sources", "ideological factors", "patriotism", "fear of flak" (if reporting is seen discouraging the war effort) and the "news values" rooted in each significant coverage (Robinson et al., 2005; cited in Murray et al.,2008, p.9). Certainly, in warlike situations, media is often considered as behaving like a "faithful servant", "publicizing official frames of [a] conflict and either ignoring or discrediting challengers" (Wolfsfeld,1997, p.69, cited in Murray et al., 2008, p.9). Examining something similar on the role of media amidst war like situations, the study intended to draw an analogy of Chinese and Indian news in communicating the Doklam standoff by using content analysis. Just like other border conflicts of the world, the Doklam standoff between India and China sparked in the summer of 2017 over China's attempt to takeover Doklam Plateau- a disputed territory, marked as a trijunction between India, Bhutan, and China. However, with the agreement to mutually withdraw troops from the border the Sino-Indian war was contained and peace ushered (Yee, 2010; Joshi, 2017; The Hindu Net Desk, 2017). The Doklam standoff 2017 was one of the major standoffs between India and China, where the media content fanned the flames. The critical role played by Indian and Chinese media in representing the Doklam standoff certainly attained special attention, given the provocative nature of the content (Pathak, 2017; Pandey, 2017). Seven sins of India, a video released by the Chinese news agency Xinhua during the Doklam standoff formed the main incentive for research as it stirred huge resentment across Indian media for its hostile content promoting racism and false statements (New China Tv ,2017; Wion,2017;

The Times of India,2017). The video by Xinhua accusing India of its mistakes was enough to reflect the Chinese psyche behind the Doklam pursuits and thus ignited a play of words (Pathak, 2017; Wion,2017). Given the interesting scenario created by media whilst communicating the Doklam tensions, the study aimed to analyse and compare the Chinese and Indian news reports on the issue. The comparison thrived on examining the cues Indian and Chinese news media offered to indicate Doklam as a part of their news agenda and what constituted the origin of their agenda. This was then further used to examine:

a. relationship of news content with China threat theory and

b. repetitions in the coverage in an attempt to create an illusory truth effect.

\section{LITERATURE REVIEW}

For much of the history, Sino-Indian relations were marked by stagnation, given the unresolved border disputes and disagreements on the territorial settlements. The "mutual suspensions over each other's military build-up" till date remain the major irritant in keeping the Sino-Indian peace. Given the unpleasant history of the two nations, how Beijing and New Delhi handle their border talks is always strategic for global peace and stability. Comparative analysis of media content in two countries is incomplete without its association with the historical context and certainly, a reference to the historic Sino-Indian border war of 1962 war is crucial for analyses in the research (Yuan, 2007, p.131). "Comparative analysis is useful in sorting out relationships between media systems and their social and political settings" (Hallin and Mancini,2004, p.4). India and China "represent two modes of civilization, demographically strong societies, and promising economic and geography forte, bringing cooperation and collaboration, coexistence and convergence, and competition and conflict on a single platform, signifying the most complex and dynamic relationship in world politics" (Panda, 2016, p.22).

Revised Version Manuscript Received on 16 September, 2019.

Saloni Gupta: Assistant Professor, Dept. of Journalism and Mass Communication, Lovely Professional University, Punjab, India.
Published By:

Blue Eyes Intelligence Engineering 
Consequently, the media system of India and China are poles apart given the huge differences in their ideologies, structure and the ownership. Acquaintance with the journalistic values of Chinese state media and free Indian media is thus critical for the present study in understanding the media representation of war-like situations (Jeffrey and Sen,2015).

The study intended to analyse all the prominent theories dealing with Sino-Indian relations and forged its association with the media representation and content. The China Threat Theory conceptualizing China's ambitious military plans certainly attained relevance in the Doklam standoff between India and China (Yee, 2010; Joshi, 2017). Against the backdrop of the Doklam standoff, the treaty of Panchsheel (Five Principles of peaceful co-existence) laying foundations for Sino-Indian peaceful relations, received a major blow. The existing literature stresses upon the relevance of the treaty post-cold war in maintaining Sino-Indian bilateral ties. However, with the onset of Doklam standoff the principles of the treaty were challenged (Sharma, 2014). Thus, the research is likely to have implications for the past generalisations and would certainly add more to the body of research existing in the area.

Media plays an instrumental role when it serves to propagandize the interests of the powerful in society. Whilst acting as an instrument it advances the important agendas of the powerful and positions them as prominent in the media policy. Thus, whatever is seen as news worthy is explained by the constraints, pressures and incentives of the hierarchical structure. The relationship is somehow a two-way process inherent with the powerful performing as the source and the media as the instrument. The government sources often enjoy special access to the media, given the amount of credibility they enjoy in being accurate and regular sources of news. Therefore, the examination of agenda setting theory of media is critical for the comparative analysis in the research as it defines media's ability to influence prominence of certain issues and to determine public opinion through a series of strategic repetitions. Indeed, media as a tool for professing governments' agenda is evident in the way certain news articles are promoted in terms of its frequency and prominence so as to draw greater public attention and creditability (Reynolds \& Mccombs, 2002; Herman \& Chomsky,1988). The existing research, though limited in nature, on media's role in Doklam standoff has alleged that Chinese media relied heavily on the idea of illusory truth effect where it repeatedly portrayed India as the aggressor. The repetition in Chinese media was seen as a move pressurized by the political regime to influence Indians to sympathize with Chinese (Pathak, 2017). Also, the studies of the past explaining the normative nature of Chinese news content discern that the coverage of the foreign nations in Chinese media corresponds to the type of relations China shares with that nation. Thus, the anti-Japanese nationalism in China owes its origin in the biased Chinese media (He,2007). The foreign news reporting is political in nature and thus embodies the foreign policies of party and the state. The Chinese government dominates the media and uses it to serve its policies. Advocating patriotism is perhaps the safest language for the Chinese media, and thus the news is framed accordingly (Zhang,2011).
The intent of the researcher can be substantiated with the rich tradition of research already existing on media's representation of war. A Corpus-Based Critical Discourse Analysis on the Israeli-Palestinian Conflict in American, Arab, and British Media analysed the language used to represent the conflict in influential media outlets by using systematic methods of linguistic analysis. It went on to generalise that "The media coverage of any conflict plays an important role in what audiences know about it and what attitudes they have towards its participants. This knowledge and these attitudes could either be a part of the solution to a given conflict, or they could be a part of the problem" (Kandil, 2009, p.33). Furthermore, the shift in the trajectory of media from objective observer to fierce advocate made Kalb and Saivetz (2007) to do a research on the role of media in the Israeli Hezbollah War of 2006. The paper reflected a comparative analysis of open journalism in Isreal vs-controlled mass media in Hezbollah and advocated that " $\mathrm{A}$ closed society can control the image and the message that it wishes to convey to the rest of the world far more effectively than can an open society, especially one engaged in an existential struggle for survival. An open society becomes the victim of its own openness" (Kalb and Saivetz, 2007, p.6).

Given that "Comparative analysis has the "capacity to render the invisible visible", to draw our attention to the aspects of any media system, including our own, "that may be taken for granted and difficult to detect when the focus is on only one national case"(Blumler and Gurevitch,2002, p.76, cited in Hallin, and Mancini, 2004,p.2), the study aspires to take up a comparative content analysis of Sino and Indian media content in communicating Doklam standoff to the public. Gans's (2004) research based on comparative content analysis of electronic and print media in America discerned about the news that was left out. His work proffered an insight into the journalistic concepts that attach value to the certain news items and further have value implications, henceforth his research is certainly substantial for making arguments on news selection in my research (Gans,2004). The existing research related to the topic is limited to the study of political cartoons in understanding Indian media's representation of the issue. It was found as to how the Indian media mocked their own country's economic distress before ridiculing the enemy and was believed to be not that hostile as the Chinese media (Pandey, 2017). Similarly, language being the researcher's barrier, no English language Chinese research on media's presentation of Doklam standoff could be traced. Thus, till date, very few scholars have worked upon the Doklam standoff as a whole, given its recent and contemporaneous nature. The existing literature on Doklam standoff is insufficient to understand the role of media during the standoff. (Pathak,2017; Pandey,2017). Thus, the study intends to bridge the gap and add to the rich tradition of research on media during the war by employing a comparative content analysis of Chinese and Indian news media content in communicating the Doklam Standoff. 


\section{THEORETICAL FRAMEWORK}

\section{The Agenda Setting Theory}

We live in a world where we deal with "second-hand reality", a reality constructed by news reports on events happening near and at far from us (Mccombs,2014, p.1). In other words, media influences our concerns about the worldly matters and play an important role in setting our agenda. By excessively and selectively focussing on few key issues and describing them in a biased fashion giving only certain details, media not only hints about its agenda setting process but also makes it certain that it has an agenda. The reality thus constructed by media determines the judgement standards of the people (Iyengar and kinder,1987).

"This role of the news media in identifying the key issues and topics of the day and their ability to influence the salience of these issues and topics on the public agenda has come to be called the agenda setting role of media" (Mccombs,2014, p.1).

There are several ways through which media influences the salience of the issues and thus subsequently gives cues to be certain about its agenda. According to Mccombs (2014) media everywhere has an agenda and the indicative cues are manifest in the three levels of media's agenda setting. The first step is creating object salience by reiterating the issue through repetitions and intensive coverage. This shows that the issue is a part of media's agenda and constitutes the cue one. The second level is talking about the agenda and unfolding the same which is called attribute agenda setting or framing where only certain aspects of the issue are revealed and are promoted in order to create a particular image and thus constitutes the second cue. And third level is where media bundles the object with other attributes or establishes relationships between the elements of its agenda to compel the public about its salience simultaneously, and thus gives the third cue. Thus, if the media is giving intensive coverage to an issue or is making repetitions of certain elements in story and is revealing only certain aspects of the issue followed by establishment of relationships between the object and other issues, then of course the media is performing all the steps of agenda setting and is ultimately hosting all the cues suggestive of a news agenda. Mccombs in his theory on agenda setting makes it clear that "sometimes attributes and framing are synonymous concepts. At other times attributes and frames are overlapping or related concepts and sometimes they are distinct concepts" (Mccombs, 2014, p.59). My research adopted this explanation and thus considered framing and attribute agenda setting as synonymous concepts in the data analysis. And in defining framing my research was based on Robert Entman's cited definition of framing:

"To frame is to select some aspects of a perceived reality and make them more salient in communication text, in such a way as to promote a particular problem definition, causal interpretation, moral evaluation and/or treatment recommendation for the item described" (Entman,1993, p.52).

A new dimension in the agenda setting is the argument "Who sets the media agenda" (Mccombs,2014, p.111). According to Mccombs (2014) there is not only the transfer of salience but even transfer of agendas in the process of agenda setting.
Therefore, media adopts an agenda, makes it its own and transfers the same to the public. The media's agenda setters can be major sources of news like government officials, other news organisations and journalistic norms and traditions. (Mccombs,2014). Adapting and exploring the theory further my research intended to examine the cues that Indian and Chinese news media hosted to indicate Doklam standoff as a part of its news agenda and further to analyse what constituted the origin of their agenda. The cues that were looked for helped in examination of the agenda setting process and ultimately the news agenda itself.

\section{The China Threat Theory}

Since 1990s the People's Republic of China has emerged as one of the world's fastest growing economy and simultaneously has created fears of regional and international stability especially in the west and among China's neighbours. Emerging in 1993 in United States, the issue of China threat has become a serious concern for many countries and consequently is affecting their perceptions towards China. The fear that China is not satisfied with the contemporary power structure and aims to replace US as a hegemonic power has nurtured the idea of 'China threat' (Yee and Storey,2002, p.2). Integral to the China threat issue is the mutual threat perceptions between China and US. ${ }^{1}$ China is very robust in its rhetoric that US is its enemy and this certainly has relevance for US security and in itself is a threat to US (Broomfield,2003). A wide array of factors ${ }^{2}$ are contributing to the notion of China Threat issue and are certainly making the world and especially China's neighbours highly anxious of China (Yee and Storey,2002, p.3; Yee and Storey,2002; Broomfield,2003). Besides the traditional and nominal threats emancipating from China's military, ideology and economy, a new wave of threat is related to information warfare. AntiChina analysts warn the world of Chinese electronic weapons and its potential to launch an information warfare attack. (Timperlake and Triplett, 2002; Broomfield,2003).

The idea that China aspires for Asian and global hegemony through its strategic expansionist policies urges many to believe China as a threat. Surprisingly, the official Chinese response to China threat theory is "defensive and rhetorical", refusing to accept that China has expansionist plans aiming to win hegemony (Yee and Feng,2002, p.36). However, its closest neighbour India thinks differently and much like the west. The China-Pakistan partnership forms the major basis of India's fear from China. China's consistent efforts to help Pakistan's nuclear programme has a direct implication for India's security concerns. Besides that, China being a nuclear country sharing a disputed border with India is a serious matter of concern for India and contributes to the threat perceptions (Garver,2002).

Garver (2002) discerns that even though China might be threatened by India but the threat is little talked about in the open publications and mass media. China has always maintained that India should not demonise it and should avoid creating unnecessary threat perceptions. The proponents of the China threat theory argue that the Chinese arguments have failed to convince that China threat is a myth and suggest that

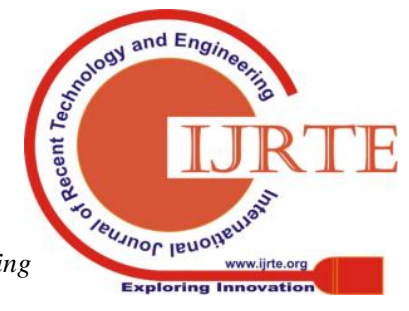


instead of being merely defensive and rhetorical it should answer in what ways China is contributing to world peace (Yee and Feng,2002). However, there are even scholars who argue that the idea that China will be aggressive on the world is flawed as China is highly dependent on the markets of US and South Asia for its economic growth. Such economic interdependence is likely to keep sober relations between China and its economic partners ${ }^{3}$ (Yee and Feng,2002; Roy,1996 cited in Broomfield, 2003).

Given the background, this research aimed to discover the ways in which the Indian and Chinese news content on Doklam standoff reinforced the China threat theory. The objective was to find the meaning latent in the news and thus was achieved during the analyses of Indian and Chinese news agenda on Doklam standoff.

\section{The Illusory Truth Effect}

The Journal of Experimental Psychology has recently found ample evidence to prove that repetition of something has enormous psychological effect and slowly makes the viewers believe it. Certainly, it is asserted that "repeated statements receive higher truth ratings than new statements, a phenomenon called the illusory truth effect" (Fazio etal., 2015 , p.993). The repeated statements are easier to comprehend relative to the new statements and this makes people arrive at false conclusions that they are more truthful (Unkelbach, 2007; Unkelbach\& Stahl, 2009). Consequently, media embodies repetitions that not only highlights its agenda but even attempts to create illusory truth effect wherein people are made to believe in repeated statements no matter they are true or not (Mccombs,2014;Unkelbach, 2007). Based on this idea, Pathak in his research on Chinese Psyche behind Doklam Standoff discerned that Chinese media attempted to create illusory truth effect by "parroting the same story of China being the victim" in order to validate China's claim (2017, p.1). However, his research lacked enough media evidence to prove the assertion. Given that, the present study intended to substantiate the previous literature with more adequate evidence of the repetitions made in Chinese news media whilst unfolding the Doklam standoff. Moreover, in fulfilment of the research objectives, the study even tried to gauge whether in comparison to the Chinese media, Indian media attempted to create illusory truth effect by making repetitions in order to validate India's claim in communicating the same. Repetitions is a pertinent way by which media highlights its agenda and is further evident in the news coverage itself, thus this objective was also achieved during the analyses of Indian and Chinese news media agenda while covering the Doklam standoff.

\section{METHODOLOGY}

Examining the role of news media in communicating the Doklam standoff the study aimed to answer the following research question:

\# What cues Indian and Chinese news media offered to indicate Doklam as a part of its news agenda and what constituted the origin of their respective media agenda?
Under this main research question the study even explored the following related questions:

- What was the relationship between the news content and China threat theory?

- To what extent the news content in both countries attempted to create illusory truth effect?

In answering the research questions, the research intended:

- To find if Doklam was an agenda of Indian and Chinese news.

- To find the origin of the agenda.

- To find the relevance of China threat theory in the content.

- To examine the attempts made by Indian and Chinese media to create illusory truth effect.

Hsieh \& Shannon define content analysis as "a research method for the subjective interpretation of the content of text data through the systematic classification process of coding and identifying themes or patterns" (2005, p.1278) and for the purpose of this study, I used the same definition as it suited the aim of the study. Given that, my research was based more on qualitative nature of content analysis which focuses on the characteristics of the "language" used, "content" or "contextual meaning of the text" (Budd, Thorp, \&Donohew, 1967; Lindkvist, 1981; McTavish \&Pirro, 1990; Tesch, 1990, cited in Hsieh and Shanon,2005, p.1278). Therefore, my study went beyond mere counting of the aspects to examine languages and draw meanings to classify voluminous texts into categories which denote similar meaning (Weber,1990). In other words, my methodology comprised a mix of quantitative (based on coding and numbers) and qualitative (based on subjective interpretation) approach to content analysis.

The analysis was done with help of contingency tables, frequency tables and pie charts. The contingency tables were used to compare same variables in two different cases i.e. news articles in Xinhua and those in PTI. The data analysis was thematic in nature and thus drew on all the concept driven themes to execute comparison between the variables and find repetitions ${ }^{4}$ (refer appendix A) (Schreier, 2012; Bryman, 2016).

\section{Sampling}

The sampling method was qualitative in nature and entailed a purposive sampling approach where relevant articles were selected from two news agencies one each from China and India, namely Xinhua and Press Trust of India (PTI) respectively (Bryman,2016). The news agencies were chosen on the basis of their reputation as the most famous national news agencies functioning as the major and most credible source of news for many media outlets..In choosing the time frame the sample was taken from the day Doklam standoff started i.e. from 16 June, 2017 till the time the standoff ended i.e. till 31 August,2017 (Bryman, 2016; Hansen et al.,1998). The standoff ended on 28 August, 2017, however there was a need to analyse some articles published immediately post

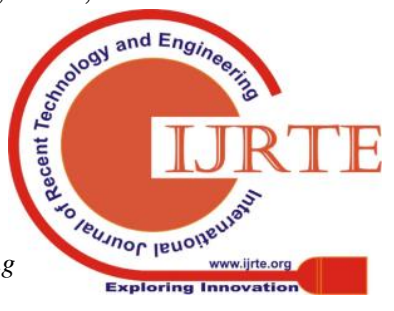


standoff and thus the time frame selected was stretched till 31 August,2017. The articles from PTI were collected using Factiva database, using the search words "Doklam" and "Doklam standoff". And for the articles from Xinhua the official English language news website of Xinhua i.e.www.xinhuanet.com/english/was used with same search words. The news items comprised all of my sample. The sample consisted of 84 news articles with 37 articles from Xinhua and 47 from PTI. Only 56 news articles about Doklam standoff could be recovered from Xinhua's news website and out of that only 37 were highly representative and were relevant for the research. From Factiva, 149 articles of PTI covering the same issue were recovered but for the sake of some equitable comparison with the 37 articles of Xinhua, 47 best articles representing PTI's coverage of Doklam were selected. The total amount of articles retrieved from each platform were further significant in my data analysis as they revealed the total amount of coverage done on the Doklam Standoff in the chosen time frame.

\section{RESULTS AND FINDINGS}

The result of the content analysis revealed that both the Indian media i.e. PTI and the Chinese media i.e. Xinhua proffered a list of cues that ascertained that both the medias were involved in the process of agenda setting, thusautomatically confirming that they had an agenda on the coverage of Doklam standoff. Enough evidence was found that not only indicated that Doklam standoff was an agenda but also gave an insight into the explicit and implicit elements of their respective agenda on Doklam standoff (table 7). Thus, the following major steps of agenda setting serving as the cues were looked for while the analysis was done.

\section{Coverage Cue}

The very first cue that was given by Xinhua and PTI to confirm that they had an agenda on Doklam standoff was the amount of coverage they gave to the issue. While Xinhua did 56 news stories on Doklam in the period of three months, PTI did a high number of 149 news stories on Doklam in the same period. Though Xinhua's count of stories falls behind PTI but its nature of content and framing of the issue was significant in labelling its coverage of Doklam standoff as an agenda (table1\&2). Therefore, in fulfilling the first step of agenda setting i.e. creating the object salience both Xinhua and PTI did regular follow ups to the news stories on Doklam and made it certain that the issue was prominent to them and thus ought to be a part of their agenda (chart 1).

Chart 4

\section{TOTAL COVERAGE IN 3 MONTHS}

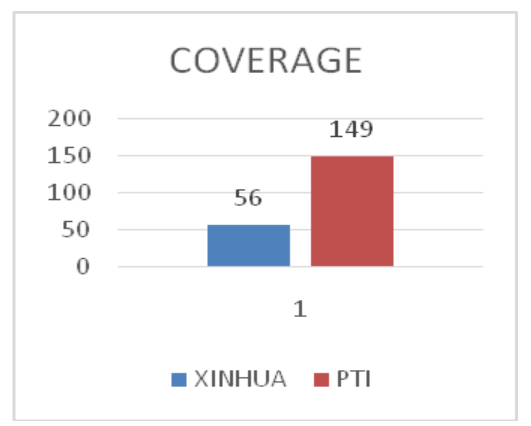

1. Attribute Agenda Setting/Framing Cue
The second cue that was hosted by both the media outlets was discussing only the selected attributes of the event and framing it in way to create a particular image of the countries involved in dispute. Therefore, the second cue highlighted what comprised of Xinhua's and PTI's agenda on Doklam standoff. To discover the attributes that were selected by Xinhua and PTI for discussion of the event the analysis of elements of main focus in the articles was done individually for both Xinhua and PTI and later was compared with each other. While some items of main focus were common in both the media outlets, some were not (table1 and 2).

\section{TABLE 1: COMMON ELEMENTS OF MAIN FOCUS}

\begin{tabular}{|c|c|c|}
\hline \multirow{2}{*}{$\begin{array}{c}\text { COMMON ELEMENTS OF MAIN } \\
\text { FOCUS }\end{array}$} & XINHUA & PTI \\
\cline { 2 - 3 } & AMOUNT EMPHASISED & AMOUNT EMPHASISED \\
\hline National claims/concerns & $18.91 \%$ & $2.12 \%$ \\
\hline $\begin{array}{c}\text { Possibility of war from our side to } \\
\text { protect our territory }\end{array}$ & $27.02 \%$ & $2.12 \%$ \\
\hline $\begin{array}{c}\text { Future threats from other side post } \\
\text { standoff }\end{array}$ & $5.40 \%$ & $2.12 \%$ \\
\hline Negative Implications besides war & $5.40 \%$ & $25.53 \%$ \\
\hline $\begin{array}{c}\text { Supporting views from around the } \\
\text { world }\end{array}$ & $5.40 \%$ & $6.38 \%$ \\
\hline
\end{tabular}

Table 2: DIFFERENT ELEMENTS OF FOCUS IN XINHUA AND PTI

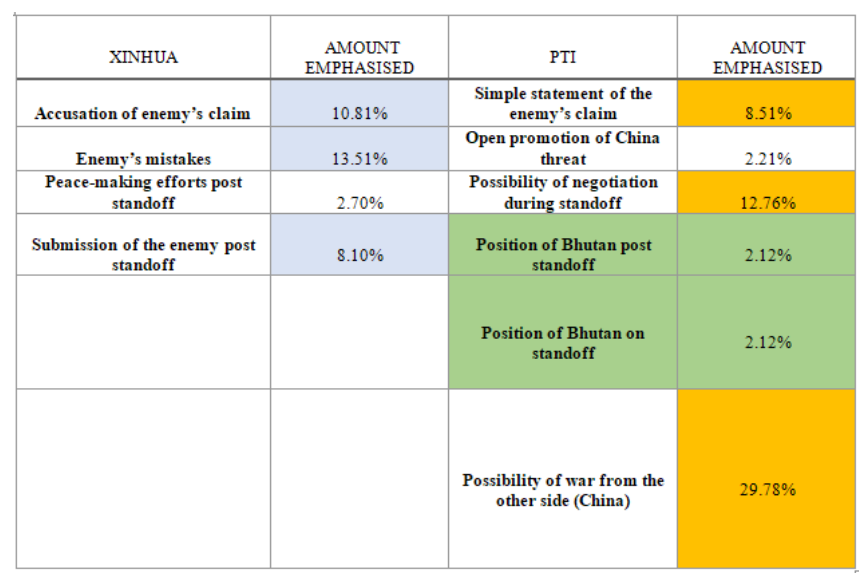

1. Establishment of Relationship Cue

The third step and cue after attribute agenda setting and framing of the event is the creation and establishment of relationships between the issues to add salience to the event. And the analysis revealed that both Xinhua and PTI actually linked Doklam standoff to other attributes and thus proffered the cue third. Thus, in attempting to bundle Doklam standoff to other attributes in order to add salience to the event, both Xinhua and PTI confirmed that they were working to transfer their agenda to the public. The comparison of the significant relations created and amount of emphasis given to them by Xinhua and PTI is summarised in table 3.

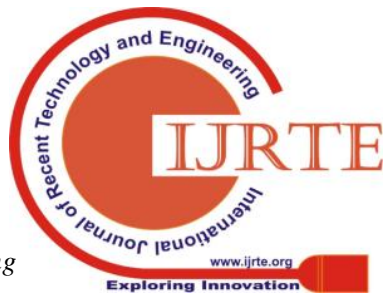




\section{Sources}

In order to find the origin of the media agenda the sources used by Xinhua and PTI were counted to find the amount of external influence in the media's perspective of the issue. And through content analysis it was found that in both the media outlets government sources played a dominant role and thus were a major source of information (table 4). While in case of Xinhua, the dependence on government sources amounted to $51 \%$ of the total, in case of PTI it was $62 \%$ of the total. Accordingly, media was seen as carrying forward the government's agenda and was communicating the same to the public. Thus, the agenda got transferred from government to the media which then certainly was aimed to influence the public agenda.

\section{Chart 5 Transfer of agenda}

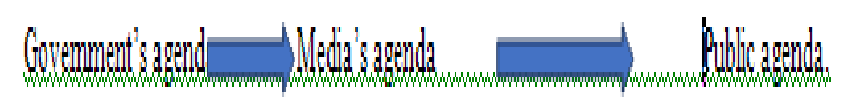

TABLE 3RELATIONSHIPS CREATED

\begin{tabular}{|c|c|c|c|c|}
\hline \multirow[t]{2}{*}{$\begin{array}{c}\text { ISSUES/ATTRIBUTES WITH } \\
\text { WHICH DOKLAMEVENT WAS } \\
\text { RELATED / BUNDLED } \\
\end{array}$} & \multicolumn{2}{|c|}{ XINHUA } & \multicolumn{2}{|c|}{ PTI } \\
\hline & $\begin{array}{l}\text { NUMBER OF } \\
\text { ARTICLES }\end{array}$ & PERCENTAGE & $\begin{array}{l}\text { NUMBER OF } \\
\text { ARTICLES }\end{array}$ & PERCENTAGE \\
\hline $1.1962 \mathrm{War}$ & 4 & $10.81 \%$ & 2 & $4.25 \%$ \\
\hline $\begin{array}{l}\text { 2.Threat To Interfere In Indo-Pak } \\
\text { Relations }\end{array}$ & 0 & 0 & 3 & $6.38 \%$ \\
\hline 3. Threat To Cyber Security & 0 & 0 & 3 & $6.38 \%$ \\
\hline 4.Entry Barriers & 1 & $2.70 \%$ & 3 & $6.38 \%$ \\
\hline \multicolumn{5}{|l|}{ 5.International Agreements/Law } \\
\hline $\begin{array}{l}5.11890 \text { Convention Between China } \\
\text { And Britain }\end{array}$ & 13 & $35.13 \%$ & 3 & $6.38 \%$ \\
\hline $\begin{array}{l}\text { 5.2 Border Agreements Between } \\
\text { China And Bhutan }\end{array}$ & 1 & $2.70 \%$ & 2 & $4.25 \%$ \\
\hline $\begin{array}{l}\text { 5.3 Border Agreaments Between } \\
\text { India And China }\end{array}$ & 1 & $2.70 \%$ & 5 & $10.63 \%$ \\
\hline $\begin{array}{l}\text { 6.National Sovereignty Concern of } \\
\text { China }\end{array}$ & 12 & $32.43 \%$ & 6 & $12.76 \%$ \\
\hline $\begin{array}{l}\text { 7.Panchsheel (Five Principles of } \\
\text { Peaceful Co-Existence) }\end{array}$ & 1 & $2.70 \%$ & 1 & $2.12 \%$ \\
\hline 8.Economic Relations & 1 & $2.70 \%$ & 3 & $6.38 \%$ \\
\hline 9. Enemy's Expansionist Plans & 1 & 2.70 & 3 & $6.38 \%$ \\
\hline \multicolumn{5}{|l|}{$\begin{array}{l}\text { 10. China's Tensions With Other } \\
\text { Countries }\end{array}$} \\
\hline 10.1 Sino-Japanese Tension & 1 & $2.70 \%$ & 0 & 0 \\
\hline 10.2 Sino-American Rivalry & 0 & 0 & 4 & $8.51 \%$ \\
\hline $\begin{array}{l}\text { 11.Threat IRCauss Territorial } \\
\text { Disintegration In India }\end{array}$ & 0 & 0 & 1 & $2.12 \%$ \\
\hline $\begin{array}{l}\text { 12. The Historical Unresolved Sino- } \\
\text { Indian Border Tensions }\end{array}$ & 0 & 0 & 3 & $6.38 \%$ \\
\hline 13. Routine Military Activities & 1 & $2.70 \%$ & 5 & $10.63 \%$ \\
\hline Total & 37 & & 47 & \\
\hline
\end{tabular}

TABLE 4SOURCES (ORIGIN OF AGENDA)

\begin{tabular}{|c|c|c|c|c|}
\hline & \multicolumn{2}{|c|}{ XINHUA } & \multicolumn{2}{c|}{ PTI } \\
\hline SOURCES & NUMBER & PERCENTAGE & NUMBER & PERCENTAGE \\
\hline 1.Government Officials & 19 & $51.35 \%$ & 29 & $61.70 \%$ \\
\hline 2.Citizens & 1 & $2.70 \%$ & 0 & 0 \\
\hline $\begin{array}{c}\text { 3.Foreigndiplomats/ } \\
\text { Scholars/ } \\
\text { Joumalists }\end{array}$ & 3 & $8.10 \%$ & 3 & $6.38 \%$ \\
\hline 4.Foreign Media & 1 & $2.70 \%$ & 13 & $27.65 \%$ \\
\hline $\begin{array}{c}\text { 5.People's Liberation Army of } \\
\text { China }\end{array}$ & 2 & $5.40 \%$ & 1 & $2.12 \%$ \\
\hline 6. Commentary / Raporters & 11 & $29.72 \%$ & 0 & 0 \\
\hline 7. Raports & 0 & $0.00 \%$ & 1 & $2.12 \%$ \\
\hline Total & 37 & & 47 & \\
\hline
\end{tabular}

The results of the main research question further helped me in exploring the two sub questions:

- What was the relationship between the news content and China threat theory?

The content analysis revealed that only specific attributes of the Doklam event were reported by both Xinhua and PTI and certain relationships were also created to add salience to the event. The analysis of those main attributes and the relationships created gave a new dimension to the findings i.e. of the China threat theory. It was found that both Xinhua and PTI reported in a way that reiterated China threat issue. While analysing the content of Xinhua, it was found that most of the reporting was done with a threatening tone regarding-: the possibilities of war with reference to Sino-Indian 1962 war, China's indominable military strength and China's decision not to compromise. Out of 37 articles analysed 20 articles were based on threatening tone and veiled threats to the India which implicitly materialised China threat issue. Consequently, the threatening tone of Xinhua resulted in a fear bound tone in PTI's articles which emphasised on promulgating the threats India was getting from China. In doing so PTI apparently escalated the fear of China implicitly. By reporting on: possibility of attack from China, threats to India's cyber security (amidst standoff), threats to India's relations internal and external, China's expansionist plan, America's support for India and official reports ascertaining China as main threat to India, PTI's articles significantly reiterated the arguments of the China threat theory in a latent fashion. Of 47 articles analysed from PTI, 33 had a fear bound tone and highlighted content that implicitly instigated China threat issue. The full comparative analysis of the elements reiterating China threat issue is summarised in table 5.

- To what extent the news content in both countries attempted to create illusory truth effect?

- Besides this, content analysis even helped to identify the repetitions made by Xinhua and PTI in their attempt to create an illusory truth effect. In Xinhua the maximum repetition was seen in citation of the 1890 convention between China and Britain and possibility of war from their side to protect their boundary. This could be discerned as out of 37 articles 13 articles related Doklam standoff with 1890 convention and 10 articles were dedicated to highlight China's intent on waging a war to save its territory. Whereas in PTI the maximum repetition was done in highlighting the fear that China might wage a war against India and in discussing the negative implications of standoff besides war. This was evident as 14 out of 47 articles analysed were based on reiterating the former and 12 were based on reinforcing the latter. The summary of the comparative analysis of the same is done in table 6 .

Henceforth, the findings not only suggested what was explicit in the news agenda, but also indicated the implicit or the undesirable (table 7). 
Table 5: ELEMENTS REINFORCING CHINA THREAT ISSUE

\begin{tabular}{|c|c|c|c|c|}
\hline PARAMETERS/VARIABLES & Xinhua & $\begin{array}{l}\text { Number } \\
\text { Of } \\
\text { Articles }\end{array}$ & PTI & $\begin{array}{c}\text { Number } \\
\text { Of } \\
\text { Article }\end{array}$ \\
\hline $\begin{array}{l}\text { 1. Tone Supporting China } \\
\text { Threat Theory }\end{array}$ & Threatening & 20 & Fear Bound & 33 \\
\hline \multirow[t]{7}{*}{$\begin{array}{l}\text { 2. Elements of Main Focus } \\
\text { That Highlighted China } \\
\text { Threat Theory }\end{array}$} & $\begin{array}{c}\text { Possibility } \\
\text { Of War } \\
\text { From Our } \\
\text { Side To } \\
\text { Protect Our } \\
\text { Territory } \\
\end{array}$ & 10 & $\begin{array}{l}\text { Possibility of } \\
\text { War From } \\
\text { Other Side }\end{array}$ & 14 \\
\hline & $\begin{array}{c}\text { Possibility } \\
\text { Of } \\
\text { Negotiation } \\
\end{array}$ & 0 & $\begin{array}{l}\text { Possibility } \\
\text { Of } \\
\text { Negotiation }\end{array}$ & 6 \\
\hline & $\begin{array}{l}\text { Possibility } \\
\text { Of War } \\
\text { From Other } \\
\text { Side }\end{array}$ & 0 & $\begin{array}{l}\text { Implications } \\
\text { Besides War }\end{array}$ & 12 \\
\hline & $\begin{array}{l}\text { Supporting } \\
\text { Views } \\
\text { FromAround } \\
\text { The World }\end{array}$ & 2 & $\begin{array}{c}\text { Open } \\
\text { Promotion } \\
\text { Of China } \\
\text { Threat } \\
\end{array}$ & 1 \\
\hline & $\begin{array}{l}\text { Military } \\
\text { Strength } \\
\text { Boasting }\end{array}$ & 1 & $\begin{array}{c}\text { Future } \\
\text { threats post } \\
\text { standoff }\end{array}$ & 1 \\
\hline & $\begin{array}{c}\text { Peace After } \\
\text { The End Of } \\
\text { Standoff }\end{array}$ & 1 & & \\
\hline & $\begin{array}{c}\text { Enemy's } \\
\text { submission } \\
\text { post standoff }\end{array}$ & 3 & & \\
\hline 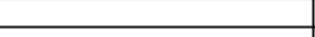 & & & & \\
\hline \multirow{6}{*}{$\begin{array}{l}\text { 3. Relationships Created } \\
\text { That Highlighted China } \\
\text { Threat Theory }\end{array}$} & 1962 War & 4 & 1962 War & 2 \\
\hline & $\begin{array}{l}\text { Sino- } \\
\text { Japanese } \\
\text { Tension }\end{array}$ & 1 & $\begin{array}{l}\text { Disturbance } \\
\text { In Indo-Pak } \\
\text { Relations } \\
\text { (China's } \\
\text { Possible } \\
\text { Interference) }\end{array}$ & 3 \\
\hline & $\begin{array}{c}\text { Routine } \\
\text { Military } \\
\text { Activities }\end{array}$ & 1 & $\begin{array}{l}\text { Threat to } \\
\text { Cyber } \\
\text { Security }\end{array}$ & 3 \\
\hline & & & $\begin{array}{c}\text { Enemy's } \\
\text { Expansionist } \\
\text { Plans }\end{array}$ & 3 \\
\hline & & & $\begin{array}{l}\text { Sino- } \\
\text { American } \\
\text { Rivalry }\end{array}$ & 4 \\
\hline & & & $\begin{array}{l}\text { Threat to } \\
\text { cause } \\
\text { territorial } \\
\text { disintegration } \\
\text { in India }\end{array}$ & 1 \\
\hline
\end{tabular}

Table 6: ATTEMPT TO CREATE ILLUSORY TRUTH SYNDROME

\begin{tabular}{|c|c|c|c|}
\hline $\begin{array}{c}\text { ITEMS } \\
\text { REPEATED } \\
\text { MAXIMUM } \\
\text { TIMES }\end{array}$ & XINHUA & $\begin{array}{l}\text { ITEMS REPEATED } \\
\text { MAXIMUM TIMES }\end{array}$ & $\begin{array}{l}\text { PRESS TRUST } \\
\text { OF INDIA }\end{array}$ \\
\hline & $\begin{array}{c}\text { Number of Times } \\
\text { Repeated }\end{array}$ & & $\begin{array}{c}\text { Number of Times } \\
\text { Repeated }\end{array}$ \\
\hline $\begin{array}{l}1890 \text { convention } \\
\text { between China } \\
\text { and Britain }\end{array}$ & 13 & $\begin{array}{c}\text { Possibility of war from } \\
\text { other side }\end{array}$ & 14 \\
\hline $\begin{array}{l}\text { Possibility of } \\
\text { war from our } \\
\text { side to protect } \\
\text { our territory }\end{array}$ & 10 & $\begin{array}{c}\text { Negative implications } \\
\text { besides war }\end{array}$ & 12 \\
\hline $\begin{array}{c}\text { National } \\
\text { claims/concerns }\end{array}$ & 7 & $\begin{array}{l}\text { Possibility of } \\
\text { negotiation }\end{array}$ & 6 \\
\hline $\begin{array}{l}\text { Enemy's } \\
\text { mistakes }\end{array}$ & 5 & $\begin{array}{l}\text { National sovereignty } \\
\text { concern of China }\end{array}$ & 6 \\
\hline $\begin{array}{l}\text { Accusation of } \\
\text { enemy's claim }\end{array}$ & 4 & $\begin{array}{c}\text { Routine military } \\
\text { activities }\end{array}$ & 5 \\
\hline 1962 war & 4 & $\begin{array}{l}\text { Simple statement of } \\
\text { enemy's claim }\end{array}$ & 4 \\
\hline
\end{tabular}
a predefined agenda on the coverage of Doklam standoff (refer to the tables above). The analysis done not only indicated that Doklam was an agenda but also gave an insight to what comprised the elements of agenda. In offering the first cue, both Xinhua and PTI created object salience by doing intensive coverage of the event in three months. While Xinhua did 56 stories in three months, PTI did a high of 149 stories in the same period. Though Xinhua's count is low but the way it framed the event it was evident that there was an agenda behind (refer table 2 and 3 ).

The second cue as per Mccombs (2014) is revelation of certain aspects of the event and framing it in a particular way to promote a specific image of the event and its members. In discovering this, it was found that both Xinhua and PTI hosted the cue and framed the issue by focussing on only certain attributes of the event (refer table $1 \& 2$ ). Thus, the findings provided enough empirical support to confirm the assertion that media not only tells what to think about but also directs how to think about that issue (Mccombs,2014; Cohen,1963; Entman,1993). For instance, the most interesting distinction was that in the entire coverage of Xinhua and PTI on Doklam standoff,the former dedicated no single story to discuss Bhutan's position on the standoff, however its counterpart PTI dedicated two full stories on Bhutan's position amidst and post standoff. Also, there were other significant differences in the statement of facts for instance, Xinhua claimed that Bhutan never sought India's help in standoff but PTI gave enough evidence to falsify that claim (appendix C). Likewise, by highlighting India's mistakes Xinhua was not only offering the second cue and was building a negative image of India, but also was revealing the value implicit that Chinese media cannot discredit the state 
government as one of its journalistic value (Hassid, 2008; Jacobs,2012; Mccombs.2014). Consequently, 27\% of Xinhua stories focussed on the possibility that China might wage a war to protect its territory. PTI also executed the task of framing by building a particular image of China, thus revealing the values implicit and explicit. By dedicating 30\% of its coverage to show China's intent to wage war, PTI was implicitly demonising China. Thus, while Chinese media took a direct route to frame India as the defaulter, India media took an indirect route to build a demonic image of China (Garver,2002). However, to argue further Indian media did not demonise China unnecessarily and rather had its own reasons for the same. Given the amount of veiled threats China gave to India in the name of war or to disturb India's relations with Pakistan or to generate pro-independence appeals in India, Indian media was bound to report it openly for the sake of objective reporting, however in doing that China got demonised (appendix C). Henceforth, the research facilitated reading between the lines and finding the values out (Gans,2004; Blumler and Gurevitch, 2002 mentioned in Hallin, and Mancini, 2004).

In discovering the cue third, the theme establishment of relationships helped to find the associations made to add salience to the event. Subsequently, it was discovered that Xinhua and PTI not only bundled Doklam event with other issues but also that those associations (table 3, appendix)implicitly provided empirical support for China threat theory. For instance, the Xinhua news articles by associating the standoff with 1962 Sino-Indian war (11\%) where China emerged victorious not only warned that the standoff might result into a full-fledged war again but also added salience by highlighting the gravity of the issue. This association further created fear of China's military strength to save its territory and thus the Chinese media in being defensive itself materialised threat perceptions against China (Yee and Feng,2002; appendix C). Similarly, other relationships were created in PTI like linking the standoff repeatedly with China's obsession with national sovereignty $(13 \%)$ to not only show that Doklam was too serious to initiate a war but also to latently expresses India's submission to China threat perceptions and to escalate fears of China (Garver,2002; Yee and Storey, 2002; Yee and Feng,2002; appendix C).

The use of sources helped to identify the major external influences on media agenda. The findings showed that the government officials were the dominant sources used in both Xinhua and PTI. Thus, all in all it was government's agenda that was being promoted and was acquired by the media in both the countries. The use of government as the major source of information not only revealed the origin of the agenda in Xinhua and PTI but also highlighted some journalistic values of media that source considerations play an important role in filtering and selection of news stories (Herman and Chomsky,1988; Mccombs,2014; Gans,2004).

Apparently, the findings significantly confirm to provide support for the China threat theory (Yee and Storey,2002). The values implicit in the content of Xinhua news on Doklam was sufficient to prove that China threat is not myth but a reality. The findings of the content analysis revealed that majority of the articles in Xinhua had a threatening tone and implicit by revealing what was undesirable and thus was left

warned India that China might wage a war to save its territoryand most significantly no single article showed China's willingness to negotiate. Thus, the findings not only questioned China's negation of the theory but also gave enough evidence to substantiate the argument that China does not really make efforts to contribute to the world peace (Yee and Feng,2002). The Indian news content acknowledged the veiled threats given through Chinese media but instead of emphasising much on stating the befitting replies and India's preparedness for war the news content in PTI gave a high weightage to restating those threats to India which implicitly confirmed India's submission to threat perceptions against China (Garver,2002). By publishing majority of the articles in fear bound tone and by discussing China's threat to wage war, PTI certainly made evident that India believes China as a threat. To reinforce further, the news content of PTI even highlighted the other threats to India that were given a refuge in Chinese media, for instance $6 \%$ of the total articles stated the warning published in Chinese media (Global times) that as a consequence of standoff, China might interfere in the Kashmir issue between India and Pakistan in the same way India is interfering in the Doklam issue between China and Bhutan (appendix C). Similarly, another PTI article by restating the threat that as consequence of standoff, China cause territorial disintegration in India,implicitly ascertained India's threat perception against China as realistic. (Garver,2002; appendix C).

The findings that $3 \%$ of total articles in Xinhua accused Japan for supported India not only highlighted anti-Japanese nationalism in China but also gave empirical support for the arguments that China considers world as a threat and Chinese news coverage of foreign nations is political in nature (Broomfield,2003; He,2007; Zhang,2011). PTI even implicitly reiterated the same argument by highlighting America's support for India during the standoff. This particular finding not only suggested the idea manifested that US backs India but even latently indicated the sour Sino-American relations which lies at the core of the China threat theory (Broomfield,2003). To discern further, PTI by highlighting America's support for India amidst standoff implicitly responded to China's threats, alarmed it and deterred it from waging a war. The findings of the news left out revealed that no single article of all the articles analysed in Xinhua focussed on America's support for India amidst standoff or India's preparedness for war, thus reinforcing the argument that even if China is threatened by India, it will not let the threat be talked about in media openly (Garver,2002). Garver discerned that threats from India in China are not talked about much because Beijing policy towards India is to court that country to 'friendship and cooperation' but the findings of the main emphasis of the Xinhua's news content suggested something different as $11 \%$ of total articles accused India of its position on Doklam and $14 \%$ of the total articles went on reminding India's mistakes amidst the standoff (2002, p122). This finding not only contradicted the argument that China loves peace but even proved that China's coverage of the foreign nation is political in nature. (Yee and Feng,20202; He,2007; Zhang,2011).

PTI drew on some more issues that implicitly reiterated China threat. Amidst covering the standoff PTI focussed on 
India's concern on safeguarding its cyber security against any information warfare attack from China (Garver,2002). This finding provides supporting evidence for the argument that world is scared of China's electronic weapons capable of crippling communication networks (Timperlake and Triplett,2002).

Revealing the implicit value further and its reinforcement of China threat notion, Xinhua articles while breaking a story on end of the standoff talked about withdrawal of Indian troops from the border, such an angle to story obviously was implicit with the desire to highlight China as the victor and India as the loser. (Yee and Storey,2002). Comparatively PTI kept silence on victory or loss post standoff, and rather dedicated $2 \%$ of the total articles to highlight China's non-committal attitude to halt road construction on the disputed territory, Doklam. By choosing to talk about the threats that might arise again in future, PTI implicitly reiterated the argument that China's neighbours are anxious of its intentions (Yee and Storey,2002; Broomfield,2003). Furthermore, the findings gave a clear evidence that China had a strong intent of war as only one article was published in the name of peace, where China hoped to maintain peace and friendship with India, however that peace was discussed only post standoff(Yee and Feng,2002). Though most of the articles in PTI highlighted the threat perceptions implicitly there was one article that was extremely explicit in suggesting the relevance of China threat; amidst standoff the article focussed on discussing the Pew research report findings that called upon China the most significant threat to India (appendix C).The finding that amidst standoff $5 \%$ of the total Xinhua articles quoted supporting comments of friendly leaders support the argument thatofficial press in China generally trivializes China's threat and shows its good image by quoting favourable comments. However, in context to the coverage of Doklam standoff the Chinese media probably failed to trivialize threat perceptions against China as the evidence found to confirm China as a threat was comparatively higher (Yee and Feng,2002).

After analysing the elements of agenda setting theory and China threat theory certain significant attributes got highlighted on the basis of the emphasis given to them. The emphasis was studied through the amount of repetition done. The findings gave enough evidence to suggest that both Xinhua and PTI resorted to repetitions tactics in an attempt to create illusory truth effect. In Xinhua most of the repetition was done with the citation of 1890 convention between China and Great Britain that stipulated Doklam as Chinese territory and was emphasised in 13 articles. This was followed by repetition of China's potential to wage a war against India which was emphasised in 10 articles. These findings provide enough empirical support the argument that China wanted to legitimize its claim on Doklam and thus kept on parroting the same thing again and again (Pathak,2017). Similar repetitions were looked for in Indian news content and illusory truth effect was created by repeating possibility of war from China, found in 14 articles and negative implications of standoff besides war to which 12 articles were dedicated. Thus, it can be stipulated that if Chinese media made such repetitions to prove itself right and defame India, Indian media made these repetitions to promulgate the China threat issue in an implicit manner and probably to attain support and sympathy for India internationally.
The findings further have implications for the past and future research as well given that my research focussed on the media coverage of the event which was less studied upon hitherto and was contemporaneous in nature. While the finding that Xinhua had an agenda on Doklam standoff that was completely biased against India and focussed only on legitimatising China's position, provide empirical support for the arguments that a closed society can control the message it wants to covey more efficiently, the finding that both Indian and Chinese news content on Doklam reinforced China threat perceptions implicitly does not provide empirical support for the argument that Panchsheel or Five Principles of Peaceful Co-existence is still relevant in maintaining Sino -Indian friendship. (Kalb, and Saivetz, 2007; Sharma,2014; Kandil,2009).

\section{CONCLUSION AND FUTURE RESEARCH}

A prominent critical aspect of this research design is qualitative element in my research as most of the decisions taken resulted in delineation of some dimensions and the analysis relied on the subjective interpretation of the researcher. Therefore, there are chances that other researchers might interpret differently given the same situation and same circumstances. All in all, the discretion to be more qualitative in my interpretation of analysis makes my research lack little objectivity and validity (Bryman,2016).

In conclusion, it is proposed that future scholars should apply triangulation of research methods and execute a large-scale study of news content of Chinese and Indian media on Doklam standoff to discover even more distinctions and similarities in the nature of their coverage (Gans,2004). Also, given the constraints of money, access and practicality, the research was based on a limited sample size having uneven number of articles from each outlet, therefore future scholars can focus on a much bigger, equitable and varied news sample from each country for greater efficiency in the comparison. Another limitation of the study was that it was significantly and largely media centric and did not consider the impact of media's agenda setting on the public agenda and thus it was difficult to comment on the success of agenda setting in both the countries chosen for study. Since the research remained limited to analysing the news agenda in China and India, the extent to which it got transferred to the public could not be studied. Consequently, the future research can focus on the audience reception of the same issue. Henceforth, the limitations of this research are opportunities in disguise to initiate future research.

\section{REFERENCES}

1. Blumler, J., \&Gurevitch, M. (2002). Towards a comparative framework for political communication research. In: Blumler, J., \&Gurevitch, M(eds.). The crisis of public communication (pp. 67-80) London: Routledge.

2. Broomfield, E.V. (2003). Perceptions of Danger: The China threat theory. Journal of Contemporary China, 12 (35), 265-284, Available from https://doi.org/10.1080/1067056022000054605 (Accessed 21 June, 2018).

3. Bryman, A. (2016). Social Research Methods, Oxford: Oxford University Press. 
4. Budd, R. W., Thorp, R. K., \&Donohew, L. (1967). Content analysis of communications. New York: Macmillan.

5. Carruthers, Susan. L. (2000). The Media at War: Communication and Conflict in the Twentieth Century. London: Macmillan.

6. Cavanagh, S. (1997). Content analysis: concepts, methods and applications. Nurse Researcher 4, 5-16.

7. Cohen, B. (1963). The press and ForeignPolicy. NJ: Princeton University Press.

8. Downe-Wamboldt, B. (1992). Content analysis: Method, applications,

9. Elo, S. \&Kyngäs, H. (2008): The Qualitative Content Analysis Process, Journalof Advanced Nursing,62 (1),107-115. Available from http://onlinelibrary.wiley.com/doi/10.1111/j.1365-2648.2007.04569. x/abstract (Accessed 23 July,2018)

10. Entman, R. (1993). Framing: Toward a clarification of a fractured paradigm. Journal of communication, 43 (4),51-58. Available from https://doi.org/10.1111/j.1460-2466.1993.tb01304.x(Accessed 24 July,2018)

11. Fazio, L.K. et al. (2015). Knowledge Does Not Protect Against Illusory Truth. Journal of Experimental Psychology, 144 (5),933-1002. Available from http://dx.doi.org/10.1037/xge0000098 (Accessed 26 June, 2018).

12. Safori, A. O., Rahman, N. A., \& Mohammed, R. (2016). The uses of social networking sites among Jordanian journalists. Internationa Journal of Communication and Media Studies (IJCMS), 6(6), 1-12.

13. Gans, H.J. (2004). Deciding what's news: A study of CBS evening news, NBC nightly news, Newsweek, and Time. USA: Northwestern University Press.

14. Garver, J. (2002). Asymmetrical Indian and Chinese threat perceptions. Journal of Strategic Studies, 25(4), 109-134. Available from https://doi.org/10.1080/01402390412331302885 (Accessed 21 June, 2018).

15. Hallin, D.C. and Mancini, P.(2004). Comparing media systems: Three models of media and politics. Cambridge: Cambridge university press.

16. Hansen, A. et al. (1998). Mass Communication Research Methods. UK: PALGRAVE MACMILLAN.

17. Hassid, J. (2008). Controlling the Chinese media: An uncertain business. Asian Survey, 48(3), 414-430. Available from 10.1525/as.2008.48.3.414(Accessed 6 July,2018).

18. He, Y. (2007). History, Chinese nationalism and the emerging Sino-Japanese conflict. Journal of Contemporary China, 16(50), 1-24. Available from https://doi.org/10.1080/10670560601026710 (Accessed 23 July,2018)

19. Herman, E. \& Chomsky, N. (1988). Manufacturing Consent: The Political Economy of the Mass Media. New York: Pantheon.

20. Hsieh, H. F., \& Shannon, S. E. (2005). Three approaches to qualitative content analysis. Qualitative health research, 15(9), 1277-1288. Available from https://doi.org/10.1177/1049732305276687 (Accessed 27 July,2018)

21. Iyengar, S., \& Kinder, D. R. (1987). News that matters: Television and American opinion. Chicago: University of Chicago Press.

22. Jacobs, A. (2012).Pursuing Soft Power, China Puts Stamp on Africa's News. The New York Times, 16 August. Available from https://www.nytimes.com/2012/08/17/world/africa/chinas-news-medi a-make-inroads-in-africa.html ( Accessed 6 July,2018).

23. Jeffrey, R. and Sen, R. (eds.). (2015). Media at Work in China and India: Discovering and Dissecting. India: Sage Publishing.

24. Joshi, M. (2017). Doklam: To Start at the Very Beginning: ORF https://www.orfonline.org/wp-content/uploads/2017/08/ORF_Special Report 40_Doklam.pdf (Accessed 8 July,2018).

25. Kalb, M. and Saivetz, C.(2007). The Israeli-Hezbollah war of 2006 : The media as a weapon in asymmetrical conflict. Harvard International Journal of Press/Politics, 12(3),43-66. Available from https://doi.org/10.1177/1081180X07303934 (Accessed 7 July,2018).

26. Kandil, M.A. (2009). The Israeli-Palestinian conflict in American, Arab, and British media: Corpus-based critical discourse analysis. Available from:http://scholarworks.gsu.edu/alesl diss (Accessed 26 July,2018).

27. Krippendorff, K. (1980). Content Analysis: An Introduction to its Methodology, London: Sage Publications.

28. Kumar, K. J. (2000). Mass Communication in India. India: Jaico Publishing House.

29. Lindkvist, K. (1981). Approaches to textual analysis. In: K. E. Sage, 23-41. and issues. Health Care for Women International, 13, 313-321. Special Report. Available from Rosengren (Ed.), Advances in content analysis. Beverly Hills, CA

30. Malek, A., \&Kavoori, A. P. (eds.). (2000). The global dynamics of news: Studies in international news coverage and news agenda. USA: Ablex Publishing Corporation.

31. Mccombs, M. (2014). Setting the agenda: Mass media and public opinion, $2^{\text {nd }}$ edition. Cambridge, UK: Polity Press.

32. McTavish, D.-G., \&Pirro, E.-B. (1990). Contextual content analysis Quality and Quantity, 24, 245-265.

33. Mehta, D. S. (1979). Mass Communication and Journalism in India. India: Allied Publishers.

34. Khan, M., \& Ayyoob, M. (2017). Cyber Security and Ethics on Social Media. Journal of Modern Developments in Applied Engineering \& Technology Research, 1(2), 51-58.

35. Murray, C., Parry, K., Robinson, P. and Goddard, P. (2008). Reporting dissent in wartime: British press, the anti-war movement and the 2003 Iraq War. European Journal of Communication, 23(1),7-27. Available from https://doi.org/10.1177/0267323107085836 (Accessed 3 July, 2018).

36. New China Tv (2017). The Spark |:7 sins of India. Youtube. Available from https://www.youtube.com/watch? $\mathrm{v}=\mathrm{OD} 27 \mathrm{woHDWbo \& t}=5 \mathrm{~s}$ (Accessed 25 December, 2018).

37. Panda, J.P. (2016). India-China relations: politics of resources, identity and authority in a multipolar world order. London and New York: Routledge, Taylor \& Francis.

38. Pandey, A. (2017). The Doklam Standoff Seen Through Cartoons. Available from http://dx.doi.org/10.2139/ssrn.3031649 (Accessed 7 July,2018).

39. Pathak, S. (2017). The Chinese Psyche behind playing the Doklam Game with India. IndrStra Global, 3(8), 3. Available from http://nbn-resolving.de/urn:nbn:de:0168-ssoar-53428-4 ( Accessed 8 July,2018).

40. Press Council of India. (2010). Norms of Journalistic Conduct. Available

http://www.presscouncil.nic.in/OldWebsite/NORMS-2010.pdf Accessed 25 july,2018).

41. Punch, K. F. (2005) Introduction to Social Research: Quantitative and QualitativeApproaches, 2nd Edition, London: Sage Publications.

42. Reynolds, A., \& Mccombs, M. (2002). News Influence on Our Pictures in the World. In:Jennings, B. et al. (eds.) Media Effects: Advances in Theory and Research (2 ${ }^{\text {nd }}$ ed pp.1-18). NJ: Lawrence Erlbaum,.

43. Robinson, P., Brown, R., Goddard, P., \& Parry, K. (2005). War and media. Media, Culture \& Society, 27(6), 951-959. Available from https://doi.org/10.1177/0163443705057685 (Accessed 7 July,2018).

44. Roy, D. (1996). The" China threat" issue: Major arguments. Asian Survey, 36(8), 758-771. California: University of California Press. Available from https://www.jstor.org/stable/2645437 (Accessed 28 July,2018).

45. Sandelowski, M. (1993). Theory unmasked: the uses and guises of theory in qualitative research. Research in Nursing \& Health 16 213-218.

46. Schreier, M. (2012). Qualitative Content Analysis In Practice, London: Sage Publications ltd.

47. Sharma, V. (2014).Relevancy of Five Principles of Peaceful Coexistence (Panchsheel) in Post-Cold War Era. Asian Journal of Multidisciplinary Studies, 2(5).

48. Taylor, Philip M. (1992).War and the Media: Propaganda and Persuasion in the Gulf War. Manchester: Manchester University Press.

49. Shivraj, P., \& Philip, H. (2016). Role of mass media in changing awareness level on climate change among small and marginal paddy farmers of Tamil Nadu. Int J Humanities and Soc Sci Interventions, $5(4), 45-50$

50. Tesch, R. (1990). Qualitative research: Analysis types and software tools. Bristol, PA: Falmer.

51. The Hindu Net Desk. (2017). Timeline: the story of the Doklam Standoff. The Hindu, 28 August. Available from https://www.thehindu.com/news/national/timeline-the-story-of-the-do klam-stand-off/article19576380.ece (Accessed 1 June, 2018).

52. The Times of India (2017). China mocks India with racist video over Doklam standoff. Youtube. Available from https://www.youtube.com/watch?v=qX_xJ4BLct0\&t=67s （Accessed 25 December, 2018)

53. Timperlake, E., \& Triplett, W. C. (2002). Red dragon rising. Communist China's military threat to America. Washington: Regnery Publishing.

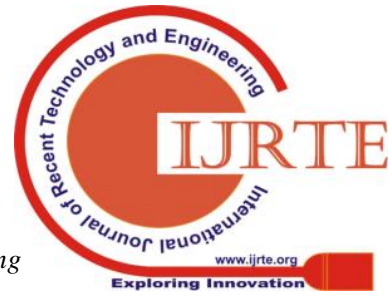


54. Unkelbach, C. (2007). Reversing the truth effect: Learning the interpretation of processing fluency in judgments of truth. Journal of Experimental Psychology: Learning, Memory, and Cognition, 33(1), $219 \quad-230 . \quad$ Available from http://dx.doi.org/10.1037/0278-7393.33.1.219 (Accessed 24 June, 2018).

55. Unkelbach, C., \& Stahl, C. (2009). A multinomial modeling approach to dissociate different components of the truth effect. Consciousness and Cognition, 18, 22-38. Available from http://dx.doi.org/10.1016/i.concog.2008.09.006 (Accessed 26 June,2018).

56. Weber, R. P. (1990). Basic content analysis. Beverly Hills, CA: Sage.

57. Wion (2017). Wion responds to China's "Seven Sins"video. Youtube. Available

from

https://www.youtube.com/watch?v=6xh_TWsCJuw\&t=6s--

(Accessed 25 December, 2017).

58. Wolfsfeld, G. (1997) Media and Political Conflict: News from the Middle East. Cambridge: Cambridge University Press.

59. Yee, H. and Storey, I. (eds.) (2002). The China Threat: Perceptions, Myths and Reality. London: Routledge Curzon.

60. Yee, H.S. (ed). (2010). China's rise-threat or opportunity? London \& New York: Routledge.

61. Vanan, C. K., \& Subramani, R. (2015). Digital divide: rural and urban college students 'attitude towards technology acceptance. International Journal of Communication and Media Studies (IJCMS), 5(4), 1-8.

62. Yee,H. and Feng,Z. (2002). Chinese Perceptions of the China Threat: Myth or Reality? In: Yee, H. and Storey,I. (eds.). The China Threat: Perceptions, Myths and Reality (pp. 21-42). London: Routledge Curzon.

63. Yuan, J.D. (2007). The dragon and the elephant: Chinese-Indian relations in the 21st century. Washington Quarterly, 30(3),131-144. Available from https://doi.org/10.1162/wash.2007.30.3.131 (Accessed 9 July,2018).

64. Zhang, L. (2011). China's National Interests, Foreign Policy, and the Media Coverage of the EU. In: News Media and EU-China Relations. New York: Palgrave Macmillan, 87-110. Available from https://doi.org/10.1057/9780230118638 5 (Accessed 25 July, 2018).

\section{WEBSITES}

1. http://www.ptinews.com/aboutpti/aboutus.aspx

2. http://www.xinhuanet.com/english/

\section{DROPBOX LINKS}

1. Coding sheets \& Full graphical analysis

https://www.dropbox.com/s/rdob9cxuze4zlqa/CODING\%20\%26\%20FUL

L\%20ANALYSIS.xlsx?dl=0

2. Full data of articles analysed

https://www.dropbox.com/s/oqy4hq5hnn09a59/full\%20data\%20of\%20arti cles.pdf?dl=0

3. Appendices

https://www.dropbox.com/s/1nb187xe9wwrc7b/appendix.docx?dl=0 